\title{
THE ROLE OF THE JOURNALIST AND MASS-MEDIA IN THE DEVELOPMENT OF THE SOCIETY
}

\author{
E. V. Frâncu
}

\author{
Emilian-Valentin Frâncu \\ Râmnicu Vâlcea Municipality \\ * Correspondence: Râmnicu Vâlcea, 14 G-ral Praporgescu St., Vâlcea, Romania \\ E-mail: emilian.francu@ senat.ro
}

\begin{abstract}
Referring to the role of the press, some researchers in the domain, who have mentally represented the existence of the modern society in the absence of the mass-media, concluded that, in spite of all the shortcomings of the journalist activities, one could not entirely imagine the human existence without being accompanied and influenced by the media.
\end{abstract}

Keywords: journalist, mass-media, information, press, development

\section{Introduction}

The establishment of the modern democracy has led to the growth of the press' importance, which took action in three main directions as to consolidate the democratic process in his totality; the relation between the persons led and the leaders in terms of public control on the political powers by means of the journalists; the relation between the persons led and the leader, referring to the mobilisation of the citizens and their consciousness regarding political decisions; the relation between the citizens, referring to the free competition of ideas. Thus, the journalists must represent a strong binding agent between power and public, between society and politics or between particular persons, as the massmedia is envisaged as an absolute communication environment, the only environment capable of mediating the bonds between the masses in modern societie. ${ }^{l}$.

Information - indispensable factor for the evolution of the inter-human relations

The need for information constitutes a characteristic trait of the human being from the oldest times, which is emphasized permanently, along with the evolution of society, the evolution of the complexity of social relation at the local or international level, with the progress of science and technique, in all domains of activity, along with the multiplication of the events which are important for the community, etc.

Information - as a primordial ontological factor which stands, along with mater and energy, at the origins of the universe- represents one of the main components of the human existence, without which the progress of the society, under all its aspects and the life itself of every human would be inconceivable in its absence. It is mainly revealed by means of the journalists by different means of communication such as: journals, papers, broadcasting, television, internet, etc.

The word "information", which was taken from Latin, (informatio) by means of the French language (information), has a polysemantic character, due to the numerous senses which are imposed by the various domains and contexts in which they are used. Thus, except for the meanings used currently, it also embodies other sense, attributed either by defining itself as a term (scientific or technical), either as a concept within certain branches of philosophy or other sciences and technologies whose object of study it represents ${ }^{2}$.

\footnotetext{
${ }^{1}$ D. Pop, Mass-media şi democrația, Polirom Publishing House, Iaşi, 2001, p. 217.

${ }^{2}$ The notion of information refers to an informational process (informing activities), at the result of this process (the volume, variety of information obtained), as well as certain specific phenomenon (the informational 
The original sense of this notion - which mainly targets the communicative aspect ${ }^{3}$ and in the same time, the qualitative aspect refers to the knowledge obtained from others, by own investigations or personal research accumulated from reading, reports on recent events or which have not been priory acquired or known, materials from journals, newspapers or news bulletins; obtained by means of study or education - deducted from direct observations and own experience ${ }^{4}$.

Due to the appearance, together with the written press of other means (radio, internet), as well as the improvement of traditional transmission methods of information (the appearance of the book or electronic press), not only has the quantity of information increased, but also the transmission speed, thus creating, more useful possibilities of receiving information, as the recipients must select the sources and news they wish to access, depending on the interests and goals pursued ${ }^{5}$, being careful to avoid the "trap" of occupying their time with these steps at the expense of developing other useful activities in the personal, family and social plan.

Moreover, the journalist also has the task to filter important issues from an increasing volume of information which originate from busy and specialised domains, having the role of passing from the supplying facts to supplying senses ${ }^{6}$, the main objective being that the massmedia also achieves a cultural and educational function for the benefit of the society members.

Depending on the professionalism of the journalists, the press may embody an important educational, formative and instructive role, as the information transmitted by means of it may contribute to a more realistic knowledge of reality, which permits the guidance of human actions as to achieve the goals pursued.

\section{Journalism and the progress of the society}

In conformity with the doctrine 7 , the news media fails to "tell" people HOW to think, but frequently achieves to tell the reader WHAT to think about, depending on the representations of the news modulated by the editors and publishers of the paper they are frequently reading. .

The mass means of communication may offer identities and aspirations, supplying new behavioural models ${ }^{8}$. Thus, the journalist plays an important role in the society of the individuals ${ }^{9}$, and depending of the credibility and objectivity of the materials supplied, they create opinions, direct the values, faiths, attitudes and public behaviour ${ }^{10}$.

phenomenon, informational boom, etc). As to correctly understand the notion of information, other concepts must be taken into consideration: meaning, knowledge, truth, representation, mental stimulus, scholarship, culture, communication, redundancy, feedback, entropy, negative entropy, etc.., and the rules associated (See C. F. Popescu, Practica jurnalismului de informare. Principii, reguli, provocări, "Lucian Blaga" University Printing House, Sibiu, 1999, p. 51; Mielu Zlate, Psihologia mecanismelor cognitive, Polirom Printing House, Iaşi, 1999, p. 65).

${ }^{3}$ The communication function or the "associated" function specific to the mass-media is also known by the term of social integration function as it is considered that the process of communication also implies integration (Dorin Popa, Mass-media, astăzi, European Institute Printing House, Iaşi, 2002, p. 85).

${ }^{4}$ A. Toffler, Puterea in mişcare, Antet Printing House, Iaşi, 1995, p. 344; Melvin L. DeFleur, Sanda BallRokeach, Teorii ale comunicării de masă, Polirom Printing House, Iaşi, 1999, p. 54.

${ }^{5} \mathrm{~V}$. Traciuc, Modalități de transmitere a ştirilor in radio, in "Manual de journalism", vol. I, coordinated by M. Coman, Polirom Printing House, Iaşi, 1997, p. 149.

${ }^{6}$ Jo Bardoel, BeyondJournalism: A Profession between Information Society and Civil Society, in European Journal of Communication, 11(3), 1996, p. 297.

${ }^{7}$ B. Cohen, The Press and the Foreign Policy, Princeton University Press, Princeton, NJ, 1963, p. 13.

${ }^{8}$ W. Mills, The Power Elite, Oxford University Press, New York, 1956, p. 314, which also shows that "The information means tell the individual from the crown who he is, confers an identity and tell him what he wishes to be, thus, creating aspirations".

${ }^{9}$ Socialization also embodies the existence of important possibilities to communicate, which have become habits, between the individual and the society. It is, "in the same time, a cultural learning and conditioning, but also a cultural adaptation, prioritization and incorporation. This term finds its place in very divers theoretical currents 
The relation between journalists and the receiving public may result in three effects: strengthening the existent opinions, creating new opinions- based on the information supplied by the mass-media- and changing the opinions depending on the argumentation and veracity of the information offered by the press ${ }^{11}$.

In this manner, the mass-media has a major importance both for the evolution of the society as a whole, as well as for the documented attitude of the individuals which form it, as "people may evaluate certain tendencies and may optimise, knowingly, their decision" based on information ${ }^{12}$.

People are searching the contact with the media in certain situation and in order to find remedies against loneliness, as to create "positive" feelings or in order to define human relations" 13 .

The journalist finds himself in a key position of the society, as he fulfils an extremely complex role, due to his involvement in the information sources and the public, having the task of presenting information in conformity with the principles, rules and legal regulations specific to the journalistic activity ${ }^{14}$. In this sense, Randall shows that the role of a journalist is to acquire fresh information on things which are of public interest and to "transmit it to the readers as quick and as accurately of possible, in an honest and balanced manner" ${ }^{15}$.

As a result of his objective activity, the journalist may contribute to the understanding and rectification of the negative aspects in the social life, thus creating a perfect balance between the private interest and the public interest. As a result, by revealing extremely serious facts, the journalists brought important contributions in taking certain normalisation measures of the activities envisaged, in numerous situations, some of them proving to be of considerable importance for the smooth running of the social, economic, politic life etc. ${ }^{16}$

The advanced technologies used by the journalists in the mass-media activity substantially influences the globalisation aspects, as the people are becoming "contingently, aware of the multitude of events occurring worldwide" and which had been normally ignored. Global expansion of the modern institutions would have been impossible without the involvement of knowledge which is represented by the news" ${ }^{\text {"17 }}$.

Mass-media and democracy

The multitude of reactions towards the relation media-democracy can be reduced to two main positions: an essential one is the critique brought, which accuses the limitations

such as: cultural anthropology, genetic or inter-human psychology" (See Gilles Ferreol, Dicționar de sociologie, Polirom Printing House, Iaşi, 1998, p. 206)

${ }^{10}$ D. Şandru, S. Bocancea, Mass-media şi democrația in România postcomunistă, "Institutul European” Printing House, Iaşi, 2011, p. 91.

${ }^{11}$ See S. Chelcea, Personalitate şi societate in tranziție, "Editura Şiință şi Tehnică” Printing House, Bucharest, 1994, pp. 204 and following, which shows that the first step towards a change in attitude is the "drawing of attention concerning the message" and that then, it is necessary "for the message to be understood", and the last phase consists in "accepting the content of the respective message".

${ }^{12}$ M. Coman, Din culisele celei de-a patra puteri, Carro Printing House, 1996, p. 104.

${ }^{13}$ J.U. Rogge, K. Jensen, Everyday Life and Television in West Germany: An Empathetic-Interpretive Perspective on the Family System, Sage printing House, 1988, quoted by Roger Silverstone, Televiziunea in viața cotidiană, Polirom Printing House, Iaşi, 1999, p. 53.

${ }^{14}$ See H. J. Gans, Deciding What's News, Pantheon, New York, 1979, p. 282, which states that the news must contain a multiple orientation, reflecting on the plurality of opinions and perspectives.

${ }^{15}$ D. Randall, Jurnalistul universal, Polirom Printing House, Iaşi, 1998, p. 37.

${ }^{16}$ For example, the journalists Bob Woodward and Carl Bernstein published, in the year 1972, in the daily "Washington Post" documented information (obtained from confidential source) from which it resulted that, under the patronage of the president of the SUA, Richard Nixon and with the involvement of the Central Investigation Agency (CIA), the illegal interception of the conversations of the "democrats" was initiated, by means of a system installed at the headquarters of the Democratic Party, in the Watergate building in Washington. As a result of the disclosure made by the two journalists, the president had to resign.

${ }^{17}$ A. Giddiness, The Consequences of Modernity, Polity Press, Cambridge, 1990, pp. 75-76. 
imposed by the media logics of the classic forms of interaction, and the second one, which insists on the "co-substantial" relation between the media and the democratic opening ${ }^{18}$.

The premise of manifesting a solid opposition which represents an indispensable element of democracy is represented by the chance to freely and publicly express one's conviction by means of the media.

On the other hand, the parties that came to power are compelled, as to keep their position, to contribute to the formation of the public opinion, with the help of the mass-media, thus bringing at their disposal their own perspectives and beliefs.

Who wishes to exercise the right to free manifestation of opinions must present the possibility of being informed regarding the thinks he is interested in ${ }^{19}$. One can not form his own judgements, if he does not know the facts. All works which are of public interest and with which the citizens must be familiar with in order to form justified political judgements must be discussed publicly, as an important role in this sense is defined by the journalistic.

Only those regimes which are submitted to the attention of the public opinion, by means of the mass-media, take the political maturity of the citizens seriously, as it can not be consolidated by means of the publicity ${ }^{20}$.

The culture of the époque in which we live is related to the media and the culture of the image which developed in modernity presupposes the inter-reaction of image, sound and word in forms which create significant structures, sometimes which influences the population significantly ${ }^{21}$.

The media culture is distinguished by its variety which is continuously enriched by new technological improvements, its penetration in the most intimate spaces of the anthropology of the daily ${ }^{22}$, of the collective and individual experiences. The relation between the media culture and the industrial type culture is evident by the replication of production and reproduction models which are traced back to the mass-media ${ }^{23}$.

\section{Conclusions}

In conformity with the traditional liberal conceptions, the essential role of the journalists and the mass media is that of acting in its capacity of a watch dog (Watchdog $)^{24}$, by criticizing the wrongful measures and actions of the state ${ }^{25}$, as it considers that by revealing certain abuses to the public authorities, to the powerful institutions, in general, an

\footnotetext{
${ }^{18}$ M. Petcu, Sociologia mass-media, Dacia printing House, Cluj-Napoca, 2002, p. 147.

${ }^{19}$ D. Ş. Paraschiv, Sistemul sancțiunilor in dreptul internațional public, CH Beck printing House, Bucharest, 2012, pp. 155-156.

${ }^{20}$ Waldemar Besson, Gotthard Jasper, Das Leitbild der modernen Demokratie. Bauelemente einer freiheitlichen Staatsordnung, Bundeszentrale für politische Bildung, Bonn, 1990, pp. 30-45.

${ }^{21}$ For example, in the electoral campaign from the years 1960, Kennedy, following the Roosevelt model, who successfully used the radio - by developing a true art of the presidential communication" - realized the importance of television for an efficient communication with the electorate, thus obtaining the function of president of the USA although $84 \%$ of the papers controlled by the republicans were against him (See V. Duculescu, Constanța Călinoiu, Georgeta Duculescu, Drept constituţional comparat, Lumina Lex printing House, Bucharest, 1996, pp. 74 and foll.).

${ }^{22}$ J. Alexander, S. Seideman, Cultură şi societate. Dezbateri contemporane, "Institutul European" Printing House, 2001, pp. 223-297.

${ }^{23}$ In the USA, the internet sites had a considerable importance in the electoral campaign developed by Barack Obama by means of his supports that used means made available by the staff candidate. the key element being denominated "social networking". After president Obama raised the internet to a level of political communication, the phenomenon spread with the speed of light over the Globe (Daniel Şandru, Sorin Bocancea, [10], p. 141).

${ }^{24}$ The term of Watchdog derives from the necessities of the free market of ideas and public manifestations of the individuals. Being defenseless in the confrontation with Power, the citizen delegates part $f$ that power to the politicians, and the other part to the media in order to control the first. Thus, journalists have two main functions, namely function the activity of the politicians and to correctly inform the citizens (Doru Pop, [1], pp. 13-14).

${ }^{25}$ J. Curran, Mass-media and Society, Michael Gurevitch Printing House, Rutledge, 1991, pp. 82ff in Doru Pop, op. cit., p. 223.
} 
equilibrium may be achieved in the society which is to maintain it within the parameters of an authentic democracy.

In this sense, Jefferson declared that, if he should decide between having a government without newspapers and having newspaper without a government, he would not hesitate in choosing the second option ${ }^{26}$. Managing to impose itself with difficulty before the powers who are attempting to prohibit, control or corrupt it, the media communication is thus, in its founding inspiration, the fruit and manifestation of a fundamental liberty: the liberty of thinking and free expression ${ }^{27}$.

All powers present counter-powers, however there is only one exception which does not abide this rule: the media power. Democracies are at risk when one of the powers does not have a counter-power ${ }^{28}$.

\section{Bibliography}

D. Ş. Paraschiv, Sistemul sancțiunilor în dreptul internațional public, $\mathrm{CH}$ Beck Printing House, Bucharest, 2012;

D. Şandru, S. Bocancea, Mass-media şi democraţia în România postcomunistă, European Institute, Iaşi, 2011;

L. W. Bennet, News: The Politics of Illusion, $6^{\text {th }}$ edition, Longman, New York, 2004;

M. Petcu, Sociologia mass-media, "Dacia” Printing House, Cluj-Napoca, 2002;

D. Popa, Mass-media, astăzi, "Institutul European" Printing House, Iaşi, 2002;

D. Pop, Mass-media şi democrația, Polirom Printing House, Iaşi, 2001;

J.Alexander, S. Seideman, Cultură şi societate. Dezbateri contemporane, European Institute Printing House, 2001;

C. F. Popescu, Practica jurnalismului de informare. Principii, reguli, provocări, "Lucian Blaga" University Printing House, Sibiu, 1999;

M. Zlate, Psihologia mecanismelor cognitive, Polirom Printing House, Iaşi, 1999;

R. Silverstone, Televiziunea în viața cotidiană, Polirom Printing House, Iaşi, 1999;

Melvin L. DeFleur, Sanda Ball-Rokeach, Teorii ale comunicării de masăa, Polirom Printing House, Iaşi, 1999;

D. Randall, Jurnalistul universal, Polirom Printing House, Iaşi, 1998;

Gilles Ferreol, Dicționar de sociologie, Polirom Printing House, Iaşi, 1998; Iaşi, 1998;

G. Lochard, H. Boyer, Comunicarea mediatică, "Institutul European" Printing House,

J. N.Jeanneney, $O$ istorie a mijloacelor de comunicare, "Institutul European" Printing House Iaşi, 1997;

V. Traciuc, Modalități de transmitere a ştirilor în radio, in M. Coman (coord.), "Manual de jurnalism", vol. I, Polirom Printing House, Iaşi, 1997;

M. Coman, Din culisele celei de-a patra puteri, Carro Printing House, 1996;

J. Bardoel, Beyond Journalism: A Profession between Information Society and Civil Society, in European Journal of Communication, 11(3), 1996;

V. Duculescu, Constanța Călinoiu, Georgeta Duculescu, Drept constituţional comparat, Lumina Lex Printing House, Bucharest, 1996;

A. Toffler, Puterea în mişcare, Antet Printing House, Iaşi, 1995;

S. Chelcea, Personalitate şi societate în tranziţie, "Editura Şiință şi Tehnică" Printing House, Bucharest, 1994;

\footnotetext{
${ }^{26}$ L. W. Bennet, News: The Politics of Illusion, $6^{\text {th }}$ edition, Longman, New York, 2004, p. 141, which also stated: "People are the only censors of those they lead and must be in possession of complete information regarding their actions by means of newspapers".

${ }^{27}$ G. Lochard, H. Boyer, Comunicarea mediatică, "Institutul European” Printing House, Iaşi, 1998, p. 6.

${ }^{28}$ J. N. Jeanneney, O istorie a mijloacelor de comunicare, "Institutul European” Printing House, Iaşi, 1997, p. VII.
} 
J. Curran, Mass-media and Society, Michael Gurevitch Printing House, Routledge, $1991 ;$

A. Giddens, The Consequences of Modernity, Polity Press, Cambridge, 1990;

W. Besson, G. Jasper, Das LeitbilddermodernenDemokratie.

BauelementeeinerfreiheitlichenStaatsordnung, BundeszentralefürpolitischeBildung, Bonn, 1990;

H. J. Gans, Deciding What's News, Pantheon, New York, 1979;

B. Cohen, The Press and the Foreign Policy, Princeton University Press, Princeton, NJ, 1963;

W. Mills, The Power Elite, Oxford University Press, New York, 1956. 